\title{
Service Quality Related to Customer Satisfaction with Umrah Worship Package Preparation at PT. Marco Tour and Travel Jakarta: Spearman's Correlation Coefficient
}

\author{
Mohammad Ridha ${ }^{*}$, Rana Harris \\ Office Administration and Secretary Laboratory, Vocational Education Program, Universitas Indonesia \\ *Email: ridho.mohammad@gmail.com
}

\begin{abstract}
This study aims to determine the level of service quality (SERVQUAL) for umrah package preparation at PT. Marco Tour and Travel Jakarta. Umrah is a journey of worship for Muslims that requires careful preparation. Customers who engage the umrah service go through various procedures such as administrative registration, payment, and manasik (training). The study focuses on customer perceptions of the application of SERVQUAL at PT. Marco. The method used is to categorize the various facilities and services into the SERVQUAL Parahsuraman factors, consisting of Tangible, Reliability, Responsiveness, Assurance, and Empathy. Respondents for this research are customers who have arrived at the final step of the preparation process for umrah worship, that is, manasik. A random sample method was used to evaluate the respondents. Researchers surmise the presence of monolithic correlations between variables with highly variable correlations. Identification of correlations between variables is expected to show the variables that indicate the characteristics of the umrah service industry.
\end{abstract}

Keywords: SERVQUAL, customer satisfaction, umrah, tour and travel, Parasurahman, Spearman, social innovation

\section{Introduction}

Indonesia has the largest Muslim population in the world. One of the requirements of Muslims is to perform the hajj and umrah as a form of the embodiment of gratitude and activity approach to God. The hajj and umrah are activities that can be categorized as Islamic tourism. The series of hajj and umrah activities is complex, from the administrative process in Indonesia, to payment, to counseling, to manasik (training), to departure to the airport, to the main activities that take place in Mecca and Medina. Travel agencies that arrange services for the hajj and umrah have grown rapidly to meet the needs of people for a professional service. The hajj and umrah is the ideal of every Muslim, especially if a prospective pilgrim can perform the pilgrimage and umrah by expectations and desires. Every prospective pilgrim hopes to receive good service, to be safe and comfortable, to pay an affordable cost, and that worship can be carried out perfectly. For that almost all the pilgrims and umrah willing to provide good and satisfactory service.

Given the religious importance of Mecca, those visiting there undoubtedly travel with a preconceived notion of what to expect from Islam's holiest city, and religious travel has proven an increasingly prevalent and interesting area for research, with particular attention paid to the motivations, expectations, needs, and experiences of those undertaking such travel (Eid \& El-Gohary, 2014; Eid \& El-Gohary, 2015; Jutla, Bodorik, \& Dhaliwal, 2002; Kim, Im, \& King, 2015; Oktadiana, Pearce, \& Chon, 2016). With this in mind, Prayag and Hosany (2014) classify travel motivations into two categories. The first concerns self-serving factors, such as a need for relaxation or a desire to experience something different, which "push" an individual toward more general travel. In contrast, they suggest that the perceived notion of destination-led attributes, such as natural resources, cultural attractions, facilities, and the general ambience, serve to "pull" tourists toward specific destinations (Gannon, 2017; Prayag \& Hosany, 2014).

The hajj and umrah pilgrimage business, like any other business institutions, has the purpose of obtaining and retaining customers. To achieve the goal of umrah worship successfully and to achieve a business's targets, it is necessary to have mature management in the field of services, counseling and guidance, manasik, and so forth. Hajj and umrah hajj companies compete for the business of pilgrims, offering coaching, services, and protection with varying facilities. In the Big Indonesian Dictionary (KBBI) the terms "travel" or "travel bureau" are defined as a travel company (that provides tickets, lodging, passport, and so on). Travel or travel bureau can also mean a provider of travel services or travel consisting of land, sea, and air transportation. A travel bureau 
should be able to provide a wide range of services, such as guide facilities and tour packages that tourists can choose from, and serve tourists who want to find tickets at a low price as well.

PT. Marco Tour \& Travel is one of the travel agents in Jakarta that is a registered member of the Association of Indonesian Tours and Travel Agencies (ASITA), the Umrah and Hajj Organization (HIMPUH), and the International Air Transport Association (IATA). PT. Marco Tour and Travel strives to offer a service that can meet customer satisfaction to prepare the company for the development of an increasingly competitive business world.

Customer satisfaction always influences buyers' repurchase intention through positive word-of-mouth interaction, whereas dissatisfaction leads to negative word-of-mouth communication (Selvakumar, 2015). Customers who are hajj and umrah pilgrims demand excellent service and anticipate that their expectations, physical and spiritual, will be met. The religious journey is different from regular travel due to the need for special handling of the guarantee of the peace of worship, which is obtained through the guidance of a companion (tour guide) who is competent. The elements of innovation and transportation facilities need to be optimized for quality.

According to the transcendent view, quality means "innate excellence." It is a mark of uncompromising standards and high achievement, universally recognizable, and recognized only through experience (Yarimoglu, 2014). The quality of service in the implementation of the hajj and umrah is assessed through a series of integrated activities, starting when the prospective pilgrims are still in the country, and continuing with the travel from the hajj dormitory to the airport, the air travel, trips in Mecca to the Grand Mosque, trips to historical places, travel in Madinah to the Nabawi Mosque, and additional packages to the city of Jeddah, and to Turkey and other countries.

Service quality has been defined by Czepiel (1990) as customer perception of how well a service meets or exceeds their expectations service quality is commonly noted as a critical prerequisite and determinant of competitiveness for establishing and sustaining satisfying relationships with customers (Agyapong, 2010).

If the expectations of customers (candidate pilgrims) who follow the activities of hajj and umrah are fulfilled, it can be a positive publication for PT. Marco to improve his company's reputation. Customers who have their expectations met may spread word of their experiences to families, relatives, and others, who in turn will likely become new customers.

Customer expectation is important in global competition, according to Parasuraman, Berry, \& Zeithaml (1991). In the marketing literature, customer satisfaction is considered a crucial factor that influences customer loyalty (Gerpott et al., 2001; Irfan, 2016; Kim et al., 2015; Kim et al., 2016; Kumar et al., 2013).

The addition of new customers will increase the profit of PT. Marco and steadily establish its position among its peers. Innovation and consistency in service procedures can keep the service quality stable. Good customer satisfaction affects the profitability of nearly every business. For example, when customers feel they receive good service, they will typically tell nine to ten people (Naik, 2010).

The consequences of not satisfying customers can be severe. According to Hoyer, MacInnis, and Pieters (2001), dissatisfied consumers can decide to discontinue purchasing a good or service, complain to the company or a third party, and perhaps return the good or engage in negative word-of-mouth communication (Singh, 2016).

Researchers typically analyze the results of research data by using the Spearman coefficient correlation method rather than the Pearson method, which is also often used. Sometimes, variables may be connected without being in linear relation, and in that case the Pearson correlation coefficient should be calculated (Udovicic, Baždarić, Bilić-Zulle, \& Petrovečki, 2007). In such cases, and when the assumption of the bivariate normal distribution, is not tenable, Spearman's correlation coefficient (rs) should be used (Artusi, Verderio, \& Marubini, 2002). Spearman's rank correlation coefficient, named after Charles Spearman, is a nonparametric measure of the relation between variables, and it uses ranks to calculate the correlation (Rebekic, Loncaric, Petrovic, \& Maric, 2015).

Service Quality (SERVQUAL) measurements underwent some improvements. Researchers are trying to adjust to the current times, especially in today's era of Digital 4.0, with the demands of customers getting higher because they want to access the standard of service online, and with competition in the service field getting tighter.

It must be recognized that service quality is an elusive concept and that there continues to be difficulty regarding the appropriateness of measurement scales. After Lewis and Booms (1983) defined service quality as how well a given service level delivered to customers meets their expectations, a number of researchers agreed that service quality is an attitude regarding the total judgment about service superiority (Banahene, 2017; Parasuraman et al., 1988).

Business in the field of services needs to implement service standards that are tailored to the wishes of customers. Conditions in the field are complex, and management expects them to conform to predefined standards, but customer dissatisfaction often results in customer complaints. 
Service quality has been variously defined as focusing on meeting a customer's requirements, and how well the service delivered matches the customer's expectations. (See, for example, Adil, 2013; Grönroos, 1984; Parasuraman et al., 1985).

The implementation of umrah worship involves several parties, namely, the government, travel agencies, and the community as consumers and potential customers. The journey of worship has business characteristics that touch on the social needs of the community. In this era of disruption, a new strategy called social innovation has emerged.

\section{Literature Review}

\subsection{Service Quality}

Quality of service can be defined as "a measure of how good the level of service provided can match customer expectations." Based on this definition, quality of service is determined by the ability of a company to meet customer needs and desires. (Ciptono, 2011: 157).

Researchers have observed that some areas of the service industry, such as retail, banking, and education, have a proximity of service characteristics. Parasurahman et al. (1985) identify five main dimensions arranged in order of their relative importance: Reliability, relating to a company's ability to deliver accurately promised services starting from the first time; Responsiveness, regarding the willingness and ability of service providers to assist customers and respond to their requests promptly; Assurance, regarding the knowledge and propriety of employees and their ability to grow trust and confidence; Empathy, meaning that the company understands the problems of its customers and acts in their interests, gives personal attention to customers, and has reasonable operating hours; Physical evidence (Tangibles), regarding the physical appearance of service facilities, equipment, human resources, and corporate communication materials.

The author adjusts these five dimensions with the characteristics applicable to educational institutions. Goetsch and Davis (1994: 16) found that quality is a dynamic condition associated with products, services, people, processes, and environments that meet or exceed expectations.

Quality is usually always associated with productivity and profitability. Nevertheless, these three concepts have their respective emphases: productivity, emphasis on resource utilization, often followed by cost reduction and model rationization. The main focus is on production. Quality further emphasizes the aspects of customer satisfaction and income. The main focus is customer utility. Profitability is the result of the relationship between income, cost, and capital used.

The message is clear: customer satisfaction is essential for the success - and continued success-of any business. Not only does positive customer satisfaction help a business, but also a lack of satisfaction takes an even bigger toll on the bottom line. For an organization to remain solvent, information regarding customer satisfaction must be adequately collected and analyzed (Ilieska, 2013).

They were further factorized or consolidated into five broad constructs, namely, tangibility, reliability, responsiveness, assurance, and empathy, due to their tendency to be repeated. Tangibility covers the existence of physical and functional facilities, equipment, experienced/knowledgeable personnel, and communication materials used in rendering and promoting effective services in libraries. Reliability involves the ability to provide, dependably and accurately, the promised services or resources needed by users in a way that can satisfy the expectations of library users. Responsiveness measures the "willingness of an organization's staff to help customers and provide them with prompt services" (Asogwa, 2014).

\subsection{Social Innovations}

Social innovations can be defined as new strategies, products, services, and organizations that simultaneously meet social needs of all kinds (more effectively than other alternatives), create new social relationships and collaborations, and enhance civil society (Jaroslava, 2015).

Researchers have noticed that social innovations need to be applied in the umrah travel business in order for companies to thrive in this disruptive era.

\section{Method}

The researchers limit this study to customer service provided by PT. Marco Tour and Travel during the preparation process before departure for umrah worship. The umrah preparation process includes administrative functions, payment, extension and manasik, and departure to the airport. 


\subsection{Research Model}

The research model used is derived from the service quality model developed by Parasurahman et al. (1990).

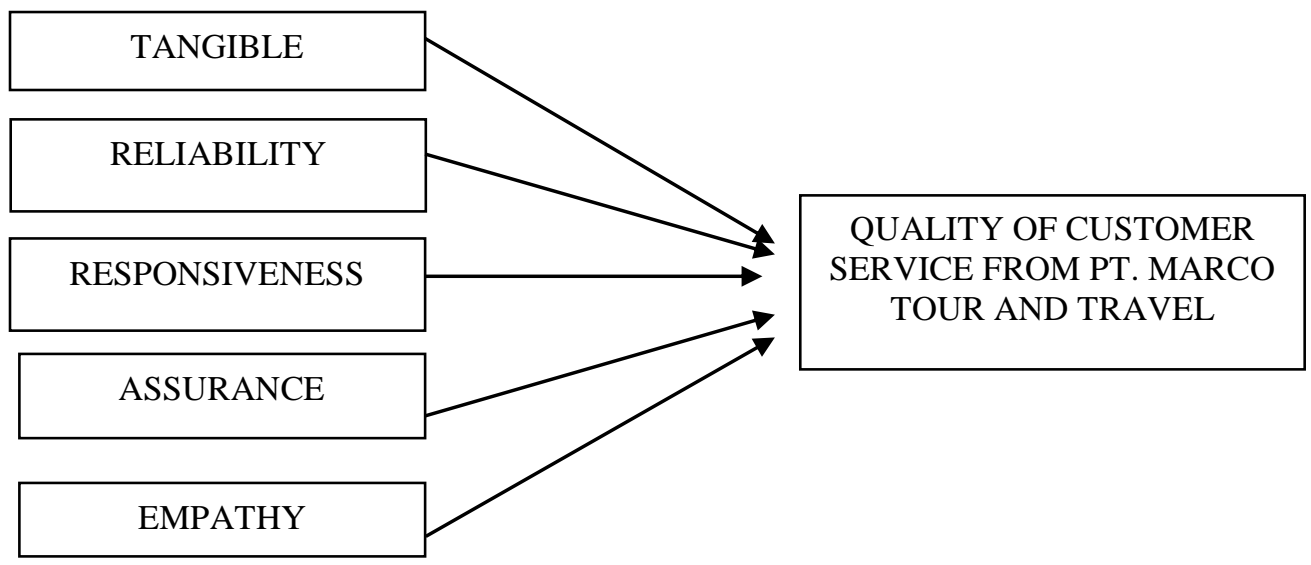

\subsection{Research Variables}

Table 1 Research Variables Derived from Research Models

\begin{tabular}{|c|c|c|}
\hline DIMENSION & NO & INFORMATION \\
\hline \multirow{4}{*}{ TANGIBLE } & 1 & Employees look neat and clean \\
\hline & 2 & $\begin{array}{l}\text { Customers get proper equipment for } \\
\text { umrah worship }\end{array}$ \\
\hline & 3 & The office room is clean and comfortable \\
\hline & 4 & $\begin{array}{l}\text { Clear information and instructions } \\
\text { (banners and brochures) }\end{array}$ \\
\hline \multirow{4}{*}{ RESPONSIVENESS } & 5 & $\begin{array}{l}\text { Employees provide service quickly and } \\
\text { with agility }\end{array}$ \\
\hline & 6 & $\begin{array}{l}\text { Willingness of employees to help } \\
\text { customers }\end{array}$ \\
\hline & 7 & $\begin{array}{l}\text { Employees can deal with complaints from } \\
\text { customers }\end{array}$ \\
\hline & 8 & $\begin{array}{l}\text { Employees can deal with any problems } \\
\text { that arise }\end{array}$ \\
\hline \multirow{4}{*}{ RELIABILITY } & 9 & Employees provide accurate information \\
\hline & 10 & $\begin{array}{l}\text { Employees can communicate easily } \\
\text { accessible information }\end{array}$ \\
\hline & 11 & Employees provide services quickly \\
\hline & 12 & $\begin{array}{l}\text { Employees can maintain the } \\
\text { confidentiality of customer documents }\end{array}$ \\
\hline \multirow{4}{*}{ ASSURANCE } & 13 & Employees can foster trust in customers \\
\hline & 14 & Supervising skills in guiding manasik \\
\hline & 15 & $\begin{array}{l}\text { Employees know the field of umrah } \\
\text { worship services }\end{array}$ \\
\hline & 16 & Employees provide courteous service \\
\hline \multirow{4}{*}{ EMPATHY } & 17 & $\begin{array}{l}\text { Employees provide service and attention } \\
\text { to customers }\end{array}$ \\
\hline & 18 & $\begin{array}{l}\text { Employees understand the problems of } \\
\text { customers }\end{array}$ \\
\hline & 19 & $\begin{array}{l}\text { Employees maintain good relationships } \\
\text { with customers }\end{array}$ \\
\hline & 20 & $\begin{array}{l}\text { Employees provide a sense of security } \\
\text { and comfort }\end{array}$ \\
\hline
\end{tabular}

Table 1 shows the questionnaires prepared based on the research variables were distributed during the manasik (practice) of umrah in two stages on April 7, 2018, which provided answers from 15 respondents, and 
on April 21, 2018, which provided answers from 27 respondents. There were 42 total respondents to the questionnaire.

\subsubsection{Data Processing and Analysis}

The stages of data processing in this study consist of two parts: the raw data and the Spearman correlation calculation.

\subsubsection{Preparing Raw Data}

From the valid questionnaires obtained from the primary data in the form of values or numbers scale that is 1 s.d. 5 , the meaning of the numbers is as follows:

Table 2 Values or Numbers Scale

\begin{tabular}{|l|l|l|l|l|}
\hline Number 1 & Number 2 & Number 3 & Number 4 & Number 5 \\
\hline $\begin{array}{l}\text { Strongly } \\
\text { Disagree }\end{array}$ & Disagree & Hesitate & Agree & $\begin{array}{l}\text { Strongly } \\
\text { Agree }\end{array}$ \\
\hline
\end{tabular}

The data in the form of numbers (Table 2) are then tabulated in the form of individual matrices-variables, which are $\mathrm{n} \mathrm{p}$, where $\mathrm{n}$ is the number of respondents and $\mathrm{p}$ is the number of variables.

\subsubsection{Spearman Correlation Calculation}

According to Sekaran (1984), the use of higher-quality instruments will better guarantee the accuracy of the results, which will ultimately improve the scientific quality of the research. Therefore, it is necessary to assess the goodness of measure in this research. To evaluate the goodness of measure, we used the validity test, reliability test.

The analysis aims to provide interpretation of the results of data processing. This section also provides an analysis of the actions and strategies that need to be taken to improve the quality of worship services umrah PT. Marco Tour and Travel.

\section{Results and Discussion}

The raw data matrix is processed using Spearman analysis with the help of SPSS software.

By hypothesis H0: $\rho=0$ (there is no monotonic relationship between the two variables) VS H1: $\rho \neq 0$ (there is a monotonic relationship between the two variables), the following results

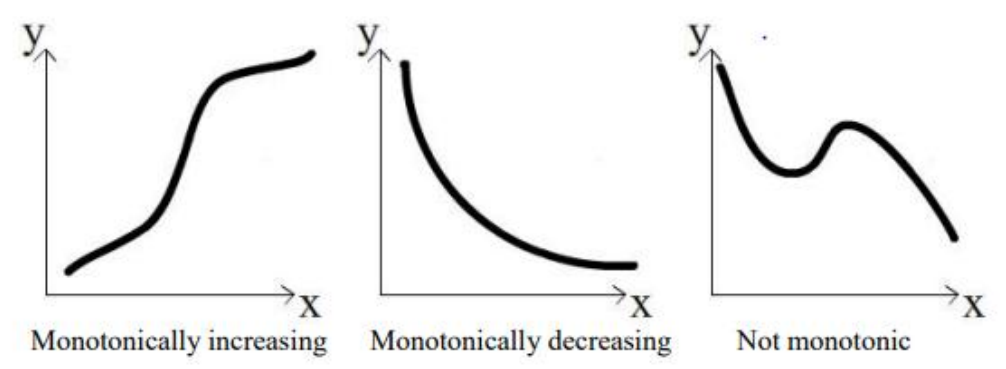

Fig. 1 The direction of monotonic

As shown in the above figure (Figure 1), $\mathrm{x}$ and $\mathrm{y}$ are positive monotonic when $\mathrm{x}$ rises, $\mathrm{y}$ tends to rise, and vice versa. $\mathrm{X}$ and $\mathrm{y}$ are negative monotonic when $\mathrm{x}$ rises, tends to fall, and vice versa. $\mathrm{X}$ and $\mathrm{y}$ are not monotonic when $\mathrm{x}$ rises, sometimes rises, sometimes falls, and vice versa.

2.In tabular form:

\begin{tabular}{|l|l|l|l|l|l|l|l|l|l|l|l|l|l|l|l|l|l|l|l|l|}
\hline $\mathrm{V}$ & 1 & 2 & 3 & 4 & 5 & 6 & 7 & 8 & 9 & 10 & 11 & 12 & 13 & 14 & 15 & 16 & 17 & 18 & 19 & 20 \\
\hline 1 & & & & & & & & & & & & & & & & & & & \\
\hline 2 & & & & & & & & & & & & & & & & & & & \\
\hline 3 & & & & & & & & & & & & & & & & & & & \\
\hline
\end{tabular}




\begin{tabular}{|c|c|c|c|c|c|c|c|c|c|c|c|c|c|c|c|c|c|c|c|c|}
\hline $\mathrm{V}$ & 1 & 2 & 3 & 4 & 5 & 6 & 7 & 8 & 9 & 10 & 11 & 12 & 13 & 14 & 15 & 16 & 17 & 18 & 19 & 20 \\
\hline 4 & & & & & & & & & & & & & & & & & & & & \\
\hline 5 & & & & & & & & & & & & & & & & & & & & \\
\hline 6 & & & & & & & & & & & & & & & & & & & & \\
\hline 7 & & & & & & & & & & & & & & & & & & & & \\
\hline 8 & & & & & & & & & & & & & & & & & & & & \\
\hline 9 & & & & & & & & & & & & & & & & & & & & \\
\hline 10 & & & & & & & & & & & & & & & & & & & & \\
\hline 11 & & & & & & & & & & & & & & & & & & & & \\
\hline 12 & & & & & & & & & & & & & & & & & & & & \\
\hline 13 & & & & & & & & & & & & & & & & & & & & \\
\hline 14 & & & & & & & & & & & & & & & & & & & & \\
\hline 15 & & & & & & & & & & & & & & & & & & & & \\
\hline 16 & & & & & & & & & & & & & & & & & & & & \\
\hline 17 & & & & & & & & & & & & & & & & & & & & \\
\hline 18 & & & & & & & & & & & & & & & & & & & & \\
\hline 19 & & & & & & & & & & & & & & & & & & & & \\
\hline 20 & & & & & & & & & & & & & & & & & & & & \\
\hline
\end{tabular}

Fig. 2 Tabular form

\section{Description:}

$\mathrm{V}:$ Variable

: there is no monotonic relationship

: there is a low monotonic relationship $(0,3-0,5)$

: there is a moderate monotonic relationship $(0,5-0,7)$

: there is a high monotonic relationship $(0,7-0,9)$

: there is a very high monotonic relationship $(0,9-1)$

As shown in Figure 2, the data explain the following:

-V7 with V8

$\mathrm{P}$ - value $0,000<\alpha 5 \%$ then Reject H0 with $\rho=0.817$, there is a strong positive monotonic relationship between

V7 and V8.

-V18 with V19

P-value $0.000<\alpha 5 \%$ then Reject H0 with $\rho=0.730$, there is a strong positive monotonic relationship between V18 and V19.

\section{Conclusion}

There is a correlation with a strong positive monotonic relationship between the following: Employees can deal with complaints from customers and employees can deal with problems that arise, and employees understand customer problems and employees maintain good relationships with customers.

* Having a low or no correlation means there is no monotonic relationship between the variables.

The variables that have a strong correlation are those associated with the dimensions of responsiveness and empathy. Service in the field of umrah services is complex, and is vulnerable to complaints from customers. Umrah is a worship activity in which all of its series have been determined the format. Customers have high expectations for the quality of service because they have to concentrate fully on worship activities, especially on extension and manasik activities. Employees who provide services for umrah activities should have competence in dealing with customer complaints and facing problems that arise at all stages. The preparation of standard 
operating procedures in the handling of customer complaints needs to be done by taking note of the documentation of complaints in the form, the selection of solutions, the delivery of solutions, follow-up, and evaluation. Employees should also be competent in understanding customer problems and maintaining good relationships with customers. Providing service for umrah worship requires a more intensive customer approach, and of course it is also supported by the dimensions of appearance, reliability, and guarantee as a holistic service.

Given that there is a strong correlation between the dimensions of responsiveness and empathy, the employees of PT. Marco should receive intensive training in the area of soft skills in dealing with others and self-regulating skills.

Soft skills are interpersonal and life skills that help the candidate share their hard skills effectively. These skills are a collection of personality traits, positive attributes, communication abilities, collective with social charm, and competencies that improve an employee's relationships and performance on the job (Binsaeed, 2017).

Enterprises in the field of umrah worship services require social innovation in management in today's disruptive era. Community needs are increasingly complex, and demands are higher. Information disclosure is increasingly massive, opening up the possibility that customer complaints can be published quickly through social media. Widespread customer complaints can reduce the level of public confidence in umrah business management. Collaboration between the umrah religious worshiper and the community needs to be woven together with a publication strategy that shows satisfied customer testimonials. The involvement of the government (Ministry of Religious Affairs) is manifested in the preparation of a standardization of umrah and hajj pilgrim services that prioritizes good relationships with customers based on empathy and preventive actions to minimize customer complaints.

The umrah travel business needs to apply social innovation to face the disruptive era of digitalization. A customer service strategy that is usually manual can be developed through Internet applications. The menu for the umrah worship service consists of a worship guide, a training schedule, a departure schedule, a return schedule, and the handling of complaints via chat, video call, and telephone. If we look at the tendency of variables that have strong correlations, they are the ones associated with the dimensions of responsiveness and empathy. The Umrah application can satisfy the customer's desire to always be served and obtain accurate information so that they can worship fervently.

\section{Acknowledgments}

Thank you to the Office Administration and Secretary Laboratory, Vocational UI, for its support and for providing the facilities and infrastructure so that this paper could be completed. The author gives high appreciation to Ms. Rana Harris as a student of Office Administration and Secretary, Vocational UI, who helped in the process of compiling this paper and distributed questionnaires at PT. Marco Tour and Travel.

\section{References}

Adil, O. (2013) Albkour, Servqual and Servperf: a review of measures in services marketing research, global journal of Management and Business Research Marketing, 13. Issue 6 (1.0 Version, Publisher: Global Journals Inc. (USA), online ISSN: 2249-4588 \& Print ISSN: 0975-5853.

Agyapong, G. K. Q. (2011). The effect of service Quality on customer satisfaction in the utility industry - A case of Vodafone (Ghana). ww.ccsenet.org/ijbm. International Journal of Business and Management. Canadian Center of Science and Education, 6(5; May), 203. https://doi.org/10.5539/ijbm.v6n5p203.

Artusi, R., Verderio, P., \& Marubini, E. (2002). Bravais-Pearson and Spearman correlation coefficients: meaning, test of hypothesis and confidence interval. The International Journal of Biological Markers, 17(2), 148-151. Pubmed:12113584.

Asogwa, B., \& E. (2014). Use of ServQUAL in the Evaluation of Service Quality of Academic Libraries in Developing Countries, Library Philosophy and Practice (e-journal) Libraries at University of Nebraska-Lincoln.

Banahene, S., Ahudey, E., \& Asamoah, A. (2017). Analysis of SERVQUAL application to service Quality measurement and its impact on loyalty in Ghanaian Private Universities. http://jms.sciedupress.com. Journal of Management and Strategy, 8(4). https://doi.org/10.5430/jms.v8n4p18.

Binsaeed, U. (2017), ISSN 23480386. Rizvi, the big impact of soft Skillsin today's workplace. International Journal of Economic, Commerce and Management, V(I, January).

Czepiel, J. A. (1990). Service encounters and service relationships: implications for research. Journal of Business Research, 20(1), 13-21. https://doi.org/10.1016/0148-2963(90)90038-F.

Eid, R., \& El-Gohary, H. (2014). Testing and validating customer relationship management implementation constructs in Egyptian tourism organizations. Journal of Travel and Tourism Marketing, 31(3), 344-365. https://doi.org/10.1080/10548408.2014.883348.

Eid, R., \& El-Gohary, H. (2015). Muslim tourist perceived value in the hospitality and tourism industry. Journal of Travel Research, 54(6), 774-787. https://doi.org/10.1177/0047287514532367. 
Gannon,M. J. Travelling for Umrah: destination attributes, destination image, and post-travel Industries. Journal ISSN, 0264-2069 (Print) 1743-9507 (Online).

Goetsch, D. L., \& Davis, S. (1994). Introduction to total Quality : Quality, productivity, competitiveness p.4. Englewood Cliffs, NJ : Prentice Hall International, Inc.

Hoyer, W. D., Macinnis, D. J., \& Pieters, R. (2001). Customer behavior. Boston: Houghton Mifflin Company.

Ilieska, K. (2013). Customer satisfaction index - as a base for strategic marketing management. TEM Journal, 2(4), 327-331.

Irfan, M. (2016), ISSN 1833-3850. How important is costumer satisfaction? Quantitative evidence from mobile telecommunication market. International Journal of Business and Management E-ISSN 1833-8119, 11(6). RemarkRemarkCanadian Center of Science and Education.

Jutla, D., Bodorik, P., \& Dhaliwal, J. (2002). Supporting the e-business readiness of small and medium-sized enterprises: approaches and metrics. Internet Research, 12(2), 139-164. https://doi.org/10.1108/10662240210422512.

Kim, S. (, Im, H. H., \& King, B. E. (2015). Muslim travelers in Asia: the destination preferences and brand perceptions of Malaysian tourists. Journal of Vacation Marketing, 21(1), 3-21. https://doi.org/10.1177/1356766714549648.

Kováčová, J. (2015). Phenomena of Social Innovation: practical attempts from Slovakia. International Journal of Social Sciences, IV(4), 30-41. https://doi.org/10.20472/SS2015.4.4.003.

Naik, C. N. K. (2010). Service Quality (Servqual) and its effect on costumer satisfaction in retailing, European. Journal of Social Sciences, 16(2).

Oktadiana, H., Pearce, P. L., \& Chon, K. (2016). Muslim travellers' needs: what don't we know? Tourism Management Perspectives, 20, 124-130. https://doi.org/10.1016/j.tmp.2016.08.004.

Parasuraman, A., Berry, L. L., \& Zeithaml, V. A. (1991). Refinement and reassessment of the SERVQUAL scale. Journal of Retailing, 67(4), 420.

Prayag, G., \& Hosany, S. (2014). When Middle East meets West: understanding the motives and perceptions of young tourists from United Arab Emirates. Tourism Management, 40, 35-45. https://doi.org/10.1016/j.tourman.2013.05.003.

Rebekic, A., Loncaric, Z., Petrovic, S., \& Maric, S. (2015) (2). Pearson's or Spearman's correlation coefficient, which one to use, poljoprivreda 21, 631(523):633.11 (pp. 47-54), ISSN 1330-7142. UDK.

Sekaran, U. (1984). Research methods for managers: a skill-building approach.

Selvakumar, J. J. (2015-August). Impact of service Quality on costumer satisfaction in public sector and provate sector banks, VII(1, March) p. 2015.

Singh, H. The importance of costumer satisfaction in relation to costumer loyalty and $\quad$ retention, UCTI, Asia Pasific University College of Technology and Innovation, Working Paper (May 2016).

Udovičić, M., Baždarić, K., Bilić-Zulle, L., \& Petrovečki, M. (2007). What we need to know when calculating the coefficient of correlation?. Biochemia medica. Biochemia Medica, 17(1), 10-15.

Yarimoglu, E. K. Y. (June 2014). A review on dimension of service Quality models. Journal of Marketing Management American Research Institute, 2(2), 79-93, ISSN: 2333-6080 (Print), 233-6099 (Online). 